\title{
The Effect of Information Technology on Learning (A Study on Civic and Pancasila Education Students at Mataram University)
}

\author{
Lalu Sumardi \\ Rispawati \\ M. Ismail \\ Universitas Mataram \\ lalusumardi@yahoo.com
}

\begin{abstract}
The aim of this research was to know how students completed their academic assignments, the reason why they completed the assignment the way they did, the effects from their choice of approach, and how to solve them. Data collection was done by using documentation, think aloud technique, and focus group discussion. The data analysis was done by using Glaser and Strauss model. The results showed that $91.1 \%$ of Civic and Pancasila Education students completed their academic assignments by copying from the Internet. Internal factors consisted of laziness, hedonistic attitude, the tendency to get everything instantly, and lack of awareness about the importance of developing positive mentality and noble character. Meanwhile, external factors consisted of the availability of information on the Internet and the type of task assigned. The effect of such tendency could be categorized into two kinds: short-term and long-term effect. The short-term effect was that the mastery of students' knowledge was only on the level of "knowing" (C1) and slightly shifted to the level of "understanding" (C2), incomplete and undetailed information about the materials, the materials were not stored in the long term memory, and the students' way of thinking was not systematic and linear. The long-term effect included the students' cognitive structure as well as their character which would not be well developed. There were two solutions to address the issue, namely instrumental and mental solution. Instrumental solution included the provision of textbooks, reference books, and the courses' list of reference books, while mental solution included developing students' awareness about the importance of scientific way of thinking, building a good attitude and character in everyday's life, including in the learning process.
\end{abstract}

Keywords: character, cognitive structure, information technology, teaching and learning

\begin{abstract}
Abstrak: Tujuan penelitian ini adalah untuk mengetahui bagaimana mahasiswa menyelesaikan tugas akademiknya, alasan mengapa mereka menyelesaikan tugas akademiknya dengan cara-cara tersebut, dampak yang ditimbulkan, dan bagaimana cara mengatasinya. Pengumpulan data dilakukan dengan dokumentasi, think aloud, dan focus group discussion (FGD). Analisis dilakukan dengan model analisis Glaser dan Strauss. Berdasarkan analisis yang dilakukan ditemukan 91,1\% mahasiswa Civic Education menyelesaikan tugas akademiknya dengan menyalin-rekat dari internet. Faktor yang menyebabkannya adalah: (1) faktor dari dalam berupa malas, hedonis, instan, dan kurangnya kesadaran tentang pentingnya membangun struktur mental dan karakter yang mulia. (2) faktor dari luar berupa tersedianya semua jenis informasi di internet dan jenis tugas yang diberikan. Dampak yang ditimbulkan adalah (1) dampak jangka pendek, yaitu penguasaan ilmu mahasiswa hanya pada level mengetahui (C1) dan sedikit bergerak ke level memahami (C2), pemahamannya tidak lengkap dan detail, materi tidak terdorong masuk dalam long terms memory, cara berpikir tidak linear dan sistematis dan (2) dampak jangka panjang, yaitu struktur mental mahasiswa tidak berkembang secara lengkap dan sikap mental berkembang kurang baik. Ada dua solusi yang dapat dilakukan untuk mengatasi masalah tersebut, yaitu (1) solusi yang bersifat instrumental, yaitu; penyediaan buku ajar, buku-buku referensi, dan daftar referensi mata kuliah; dan (2) solusi yang bersifat psikis/mental, yaitu membangun kesadaran mahasiswa tentang pentingnya membangun cara berpikir ilmiah, sikap, dan karakter yang mulya dalam kehidupan sehari-hari termasuk dalam proses pembelajaran.
\end{abstract}

Kata kunci: karakter, pembelajaran, struktur mental, teknologi informasi 
The preamble of the 1945 Constitution states that one of the national goal of Indonesia is to ensure the people intellectual capability. It is the founding fathers dream as well as the direction of the development of the nation (Budimansyah, 2015). Ensuring people intellectual capability and developing the quality of human resource become the paramount agenda and focus of Indonesia (Winataputra, 2012). The Indonesian founding fathers believed that Indonesian will become an advanced country if the human resources possess certain qualities such as intellectual, emotional, and spiritual qualities.

To achive the above-mentioned vission and dream, the one and only instrument that must be taken into account is an education element, both formal and informal and or non-formal education (Nasional, 2003). From the three approaches of educational setting, formal education is the primary concern of government. Qualified educational institution must be able to generate qualified graduates. Therefore, to achive Indonesia as a qualified and advanced country, it is important to put highest concern on education.

Currently, government has worked on developing equal, qualified, and good education through stipulation of various policies and regulations. Government through constitutional stipulation provides $20 \%$ allocation of state budget in order to intensify and extend qualified education (Supardi, 2015). However, maximum effort taken by government is not sufficient if it is not supported by the related party within educational setting.

Recently, the concerned phenomena within educational setting in Indonesia is about the quality of the next generation. It is indeed will influence on the upcoming development of nation. Recently, the young generation as the hereditary of the nation tend to be spolied by hedonism lifestyle, have no work hard attitude, choose the fastest way in doing something, and depend on the internet. In current trend of young generation, they rely on the existence of internet as the main source in completing assignment or they commonly consult on search enginee called Google (Krisnawati, 2016). Now, it becomes the main concerned since it could reduce the academic spirit, work ethic, responsibility, as well as reducing the habit of being critical, logical, and analytic within learner.

This condition, in fact and unfortunately, occurs within higher education which essentially is seen from 2013 Curriculum higher education emphasize on high-order thinking skill of the learner (Machin,
2014). Thus, it is undeniably bad if the learners in higher education are given an assignment which is actually to habituate and construct their mental structure and material mastery, but they heavily depend on intenet. This phenomena is currently happening within higher education context.

According to the above-mentioned phenomena, the author tried to uncover the phenomena and reveal what is actually happening. In addition, the author aims at revealing the reason of such phenomena, the effect of the phenomena, and how to deal with it. Therefore, it is expected that the results of this study could offer an insight regarding the occuring phenomena by presenting the real data and facts, providing an alternative solution which eventually could encourage the related party in educational setting to resolve the existing issues.

\section{METHOD}

This research employed a case study approach which took undergraduate students of Social Studies Education Faculty of Teacher Training and Education Mataram University as a research subject.

Courses taken by the students served as this research unit. The determination of subject was done through purposive sampling. In addition, the determination of sample focused on the dependency of students towards internet in finishing the assignment and based on the relationship between researcher and the subjects (Sudjana, 2006). Through purposive sampling, then, it was determined that the basic concept of Civics and Pancasila Education courses which consists of three classes were taken as a sample.

This study employed documentation, observation, and FGD (Focus Group Discussion) to collect the data. Documentation was employed to obtain data regarding how the students do the assignments (Edmunds, 2000). The data source in the documentation was papers and articles produced during classes. As for the observation, it was employed to obtain data regarding the understanding, scholarly logic, and consistency of understanding regarding the assignment given and its effect. Observation was done when the classes discussed the assignment and it employed observation sheet instrument to collect the data. Meanhwile, FGD was used to obtain data regarding te factors that might cause the students heavily depend on internet to finish their assignments.

The data obtained were then analyzed using fixed comparison analysis technique as suggested 
by Glaser and Strauss (1970) by employing data reduction (choosing data which based on the research questions and marking data with the code), categorizing (classifying data based on the research questions and sub-category of research questions), synthesizing (finding the relationship among categories of data), and framing hypothesis (generating operational statement based on the data to answer the research questions) (Lexy and Moleong, 2006).

\section{RESULTS AND DISCUSSION}

\section{Results}

\section{Composing Academic Assignments}

Behavior and action taken by individual represent and reflect tje attitude of the individual. Essentially, action taken by individual serves as indicator of value, attitude, and decision taken by the individual. In addition, it reflects the quality of individual. It is in line with Fraenkel's (1977) argument stating that Values cannot be seen directly; they must be inferred from values indicators-what people say and do. Both the actions and statements of people offer clue about their values.

Based on the analysis results of documents in the form of courses assignments, $91.1 \%$ of students took the material for their assignments directly withouth the process of thinking, reformulating, and concept reconstructing. Students only edited the layout, converted the format from PDF into Words file, and added their personal identity. Even sadly, some ofthem typed the assignements but manually wrote their identity. This results are in line with the statement expressed by subject during FGD, “...Sir, I tend to choose the fastest and easiest way to finish my assignments. It is difficult to look for the book. Internet has provided all what I need".

The data above indicates that students tend to think pragmatically and practicallyn as well as depicting that they are effortless in establishing their knowledge. The way students finsihing the assignment did not contribute to their development of knowledge and understanding. It because there was no sensing process and mental activity during the finishing of assignments. However, according to theory of information process, the obtained knowledge will inserted into memory through sensing process (Nur, 2004b; Nur et al., 2004) and constructive mental process (Ratumana, 2004).

Based on the above-mentioned data and along with the explanation theory, it proves that students did not obtain sufficient information (knowledge) regarding the concepts being studied. Thus, students will lack of information and knowledge. Moreover, the effect is the stagnancy of mental structure. Schemes within student will not be constructed completely and perfectly, because schemes will be constructed from the information which infiltrate within memory and it is systematically arranged and well-organized (Suparno, 2001). Therefore, the intellectual capacity is not well-developed.

In addition, the issues are correlated with mentality and morality aspects. The issues prove that students do not possess good mentality such as hard work, responsible, and honest which also represent a bad morality. This condition did not meet the expectation of 2013 Curriculum which demand stuents in Higher Education to have good in manner, morality, and personality. Furthermore, the issues will create systematic detriment if it is not taken into account immediately. This will be habituated to the students and at the end of the day it will become a bad culture which is difficult to be changed in the future (Darmadi, 2007).

\section{Causing Factors}

According to the Causality Law, everything happens for a reason. No phenomena and event occur without a certain reason. Everything happens due to causality law. In the perspective of religion causality law is similar with Sunnatullah. So is the phenomenon that occurs on campus, especially with regard to academic learners performing tasks almost instantaneous, pragmatic and hedonist, has a definite reason.

From the data of FGD, it was identified several reasons why learners perform actions as described above, are: laziness, the source is already available on the internet, do not have a target mastery of subjects, and do not have a definite purpose to what the study on certain subjects. Based on the above data, it can be formulated two factors causing the academic behavior of learners as described above, namely 1) The internal factor in the form of bad mental attitude; and 2) external factors such as easy access to information on the Internet and type of task assigned.

In addition to mental attitude factors, easy access to information on the internet and the availability of all types of information on the internet contribute to the sxisting the condition. The Internet provides an opportunity for learners to complete all tasks instantaneously. The internet evokes and fosters 
the sense of laziness and hedonism of learners. This condition certainly does not support the intellectual development of learners. The scheme in the learners will not be formed and developed properly, whereas theoretically the scheme will be built up well if the information is arranged and organized in the mental structure. The condition will occur if the mental structure is functioned well in obtaining the information (Vygotsky in Nur, 2004b).

The types of assignment given to the learners also contributed to the existing issue. Assignment which directs learners in obtaining information (declarative knowledge) is a potential cause of learners in taking shortcut during the completion of assignments. Learners will automatically think that the sources are ready-to-obtain from the internet. Learners with bad mental attitude will take those shortcut. They will be encouraged to do bad action during the completion of assignments. This type of motivation is a goal-oriented motivation (Nur, 2003). Unfortunately, the goal is to complete the assignment immediately and easily. Goal-oriented motivation is good if it is directed to the orientation of material mastery and mental structure development which will establish a good mental attitude and develop a learners' cognitive structure and schemes.

\section{The Impact on The Learners}

Law. No. 20 of 2003 regarding National Education System, article 3, the eight educational goals are to generate a faithful learner who believe in God, a noble learner, a healthy learner, a knowledgeable learner, a competent learner, a creative learner, an independent learner, and a democratic citizen as well as responsible individual. From the eight goals above, it can be classified into three major goals, cognitove, affective, and psychomotoric goals.

To achieve these goals, the learning must be conducted academically. In the perspective of Constructivism (Ratumana, 2004) the best learning is learning which is centered on learners, where the learners themselves build their knowledge. The impact of good learning is meaningful learning, where the mental structure will develop well along with the formation of a regular scheme that is useful in everyday life (Soeparno, 2001).

In relation to the above-mentioned explanation regarding the way learner complete the assignments, the impacts can be grouped into two broad categories: 1) short-term impact, which the learners do not understand the material well and the material will not be processed in long terms memory. Thus, the material will quickly disappear, and lessons learned are meaningless; 2) long-term impact, which deals with the mental structure of learners. The mental structure of the learners is not well developed and the mental attitude will be poor.

With regard to short-term impact, in information processing theory (Nur, 2004a) it is mentioned that the human brain works similarly to computers, as well as the data storage system. If the information on the computer is entered through the keyboard, then humans enter it through the five senses. If the computer stores data in both internal and external memory, then human stores it in sort terms memory and long term memory. The best place to store data on the computer is the flashdisk whereas for humans the best in long terms memory because it can survive for long periods of time.

Inputting information/data in long terms memory can not be done haphazardly, or by means of just a copy paste. It takes effort through the engagement of all the senses to the fullest to be able to place information in long terms memory. According to DePorter (2000) each senses has a certain capacity to enter information in the human brain. He mentioned that $10 \%$ of information goes through what we read, $20 \%$ of what we hear, $30 \%$ of what we see, $50 \%$ of what we see and hear, $70 \%$ of what we say, and $90 \%$ from what we say and do. The main requirement for the attainment of the senses function as mentioned above is the maximal functionalization of human senses. To function the senses properly it should be combined with appropriate learning strategy. The learning strategies which are appropriate for maximizing the senses are reapitation, elaboration, and PQ4R (Nur, 2004a).

For long-term impact, the mental structure and character are not well formed. Piaget (Suparno, 2001, Nur, 2004b) explains that good mental structures are mental structures in the form of schemes arranged over long periods of time. The scheme itself is a collection of information connecting to each other and the information that can form a schema is information that is constant, logical, and not contradictory to one another. Thus, a person's mental structure will not be well-formed if the amount of information placed in the cognitive order is inadequate. The scheme will not evolve to the more complex if the information that the material is not well supplied.

Individual bad character, can be explained from two perspectives, First, the action which is done continuously and repeatedly will be the character of 
the person (Darmadi, 2007). Second, moral action including the quality of one's moral actions in the view of Piaget and Kohlberg is largely determined by the development of one's cognitive structure (Nur, 2004; Kohlberg, 1995). Thus, the work done as mentioned above will build a bad morality in the learner. At least they will develop into a weak person of moral quality because it is not supported by good reasoning capability.

\section{Discussion}

\section{Knowledge and Thinking Pattern Acquisition}

According to the theory of Cognitivism, understanding is the primary goal of learning. On other words, the learning is considered successful if the learners understand the concept (Ratumana, 2004; Sagala, 2009). Based on revised theory of taxonomy of cognitive explained by Kratwohl, et al (2001), there are six stages of human thinking pattern, they are knowing, understanding, applying, analyzing, evaluating, and producing. The stages represent the order of understanding or become the standard in which certain individual is able to understand certain concept.

Based on the observation results towards teh research subject, it obtained the following data:

1. The knowledge of the subject remains on the level of knowing. Only few of them move towards the stage of understanding. They mostly tend to remebering instead of understanding the concept.

2. In understanding the concept, they are not able to construct the understanding completely and holistically. It is seen from the inconsistency of learners during the understanding stage. Initially, they are able to explainb the concept. However, if they are asked to explain it in detail, they often explain the concept incorrectly.

3. The thinking pattern of the subject is not linear, systematic, and hierarchical. They often have a contradictory pattern of thinking

The aforementioned learning outcomes is still far beyond from the standard of accomplishment. It has no benefits in the future, particularly when dealing with real life issues. According to Ausubel (Nur. 2004a), good learning is a meaningful learning. It should establish the understanding of learners and the learners must be able to apply it in daily lfe. The aforementioned learning outcomes is not belong to meaningful learning. The data above is in line with the way learners complete their assignments. It is difficult for learners to develop a cognitive level 3,4 , 5 or even 6 if the learners do the assignment through a shortcut way instead of their own thinking process. In addition, they will not have a logical, analytical, and systematical thinking.

The assignment given to learners at least aim at improving the understanding on certain concept and developing the pattern of thinking. If the learners complete the assignment by using their own thinking, their thinking pattern will be devloped. In addition, they will be habituated to dialectically think which stimulate critical, analytical, systematical, and logical thinking. It is in line with the argument of Vygotsky (Nur, 2004), states that individual intellectual will be developed when they face a new and difficult ideas. Moreover, the role of teacher is to facilitate the development of learners' thinking.

\section{How to Deal with}

From the FGD conducted there are several alternative solutions, namely; provision of textbooks as a source of learning, requiring the book as a reference of each task given, lecturers prepare reference books that can be duplicated by the learners, and provide a list of reference courses. From several alternative solutions, it can be formulated into two major solutions, instrumental and mental solution. Instrumental alternatives are the procurement and provision of learning tools in this case textbooks, reference lecture books, and reference list of courses (Sutjiono, 2005). While the mental alternative is the attempt to build learners awareness.

In building awareness, there are two steps, forcing and growing awareness from within the learners (Murwani, 2006). Building awareness from within the learners is the ultimate approach because it can be long-lasting within the individual. This can be done by awakening learners to the importance and benefits of the processes involved in building knowledge and mental structures through scientific steps, building awareness of the negative impact of long-term harmful actions, and building the value of hardworking as well as the value of honesty within the learners.

All the attempts taken by lecturers in building the awareness are to motivate the learners to change their behavior. Essentially, the one who capable of changing the behavior is the individual him or herself. Allah SWT within Al-Quran (Ar Ra'd:11) says that He will not change certain individual or group if they do not want to be changed. Motivation is very important to be done so that learners are 
encouraged to change, actively and constructively involved in academic activities (Nur, 2003). With the motivation, it is expected that learners will learn more in terms of quantity and better in terms of quality.

\section{CONCLUSION}

From the data obtained and the discussion above, it can be concluded that (1) internet is the main source of learners in completing their assignments; (2) learners have a poor mentality such as hedonism, lack of internal motivation, and a lack of academic orientation. In addition, learners tend to choose shortcuts in doing their work by plagiarizing sources from the internet. (3) It has a negative impact on the formation of mental structure and the character of the learners. (4) It need an immediate solution to solve the problem to reduce the bad impact. (5) It is important to build awareness in the learners, internalize the value of honesty and hard work in academic context.

\section{REFERENCES}

Budimansyah, D. 2015. Pembelajaran Pendidikan Kewarganegaraan Berbasis Portofolio. Jurnal Civics, 3(1).

Darmadi, H. 2007. Dasar Konsep Pendidikan Moral. Bandung: Alfabeta.

DePorter, B., Reardon, M., Singer-Nourie, S., Nilandari, \& Syahrani, F. 2000. Quantum Teaching. PT Mizan Publika.

Edmunds, H. 2000. The Focus Group Research Handbook. McGraw-Hill.

Fraenkel, J. R. 1977. How to Teach About Values: an Analytic Approach. Prentice Hall.

Glaser, B. G. \& Strauss, A. L. 1970. Theoretical Sampling. Sociological Methods a Sourcebook: 105-114. Chicago: Aldine.

Kohlberg, L. 1995. Tahap-tahap Perkembangan Moral. Yogjakarta: Kanisius.

Krathwohl, D. R., Anderson, L. W., \& Bloom, B. S. 2001 A Taxonomy for Learning, Teaching and Assesing: a Revision of Bloom's Taxonomy of Educational
Objectives. NY: Longman.

Krisnawati, E. 2016. Perilaku Konsumsi Media oleh Kalangan Remaja dalam Pencarian Informasi (Studi Kasus Perilaku Remaja di Kota Salatiga dalam Penggunaan Media Dalam Perspektif Teori Ketergantungan Media). KOMUNIKATIF, 5(1): 43-69. Lexy, J. \& Moleong, M.P.K. 2006. Bandung: Remaja Rosdakarya.

Machin, A. 2014. Implementasi Pendekatan Saintifik, Penanaman Karakter dan Konservasi pada Pembelajaran Materi Pertumbuhan. Jurnal Pendidikan IPA Indonesia, 3(1).

Murwani, E. D. 2006. Peran guru dalam membangun kesadaran kritis siswa. Jurnal Pendidikan Penabur, 6: 59-68.

Nasional, S. P. 2003. Undang-Undang Republik Indonesia nomor 20 tahun 2003. Jakarta: Depertemen Pendidikan Nasional Republik Indonesia.

Nur, M. 2003. Memotivasi Siswa untuk Belajar. Surabaya: Unesa Press.

Nur, M. 2004a. Strategi-Strategi Belajar. Surabaya: Unesa Press.

Nur, M. 2004b. Teori Perkembangan Sosial dan Moral. Surabaya: Unesa Press.

Nur, M. dkk. 2004. Teori-teori Pembelajaran Kognitif. Surabaya: Unesa Press.

Ratumana, G. T. 2004. Belajar dan Pembelajaran. Surabaya: Unesa Press..

Sagala, S. 2009. Konsep dan Makna Pembelajaran. Bandung: Alfabeta.

Sudjana, D. 2006. Evaluasi Program Pendidikan Luar Sekolah. Bandung: Remaja Rosdakarya.

Supardi, U. 2015. Arah Pendidikan di Indonesia dalam Tataran Kebijakan dan Implementasi. Formatif: Jurnal Ilmiah Pendidikan MIPA, 2(2).

Suparno, P. 2001. Teori Perkembangan Kognitif Jean Piaget. Yogjakarta: Kanisius.

Sutjiono, T. W. A. 2005. Pendayagunaan Media Pembelajaran. Jurnal Pendidikan Penabur, 4(4): 76-84.

Winataputra, U. S. 2012. Pendidikan Kewarganegaraan dalam Perspektif Pendidikan untuk Mencerdaskan Kehidupan Bangsa (Gagasan, Instrumentasi, dan Praksis). Bandung: Widya Aksara Press. 